\title{
The productivity of agrocoenosis in the steppe zone of Khakasia according to Terra Modis
}

\author{
Elena Zhukova ${ }^{1 *}$, Natalya Kutkina $^{2}$, and Alexander Zhukov ${ }^{1}$ \\ ${ }^{1}$ Federal State-Funded Educational Institution of Higher Education «Katanov Khakass State \\ University», 655017, Lenin Avenue 90, Abakan, Russia \\ ${ }^{2}$ Research Institute of Agricultural problems of Khakasia, 655132, Sadovaya st., 5 Zelenoe village, \\ Russia
}

\begin{abstract}
The article presents the results of a quantitative assessment of the productivity of agrocoenosis according to Terra MODIS within the steppe zone of Khakasia. The gross primary production of various agrocoenosis during the growing season ranges from 3.42 to $7.41 \mathrm{~kg} / \mathrm{m}^{2}$. On average, the integral productivity for the growing season of 2018 was for wheat $-5.01 \pm 1.04 \mathrm{~kg} / \mathrm{m}^{2}$, oats $-4.86 \pm 1.12 \mathrm{~kg} / \mathrm{m}^{2}$, barley $-4.52 \pm 0.42 \mathrm{~kg} / \mathrm{m}^{2}$, buckwheat $5.25 \mathrm{~kg} / \mathrm{m}^{2}$, hayfields $-4.86 \pm 0.45 \mathrm{~kg} / \mathrm{m}^{2}$, deposits $-4.39 \pm$ $0.40 \mathrm{~kg} / \mathrm{m}^{2}$. Least of all phytomass were some arable fields and low-yielding crops of wheat and abandoned lands, and most of all perennial grasses and high-yielding wheat and oats. The GPP indicators are associated with the sum of positive temperatures positively $\left(R^{2}=0.673\right)$, to a lesser extent $\left(R^{2}=0.333\right)$ with a hydrothermal coefficient for the examined agrocoenosis. The most productive crops and fertile territories were determined based on the seasonal and long-term dynamics of gross productivity. An increase in productivity for some agrocenoses was noted in 2018 according to satellite data.
\end{abstract}

\section{Introduction}

Khakasia belongs to territories with an unstable structure of agricultural land using due to the influence of natural and anthropogenic factors, in particular the subarid climate, decreased fertility, salinization, and soil erosion and grazing. The Beisk coal deposit is located in the study area, and the coal industry is developing intensively [1]. A regular monitoring of agrocoenosis is necessary under these conditions. Remote sensing tools can significantly simplify the task of assessing the state of various plant communities throughout the growing season by ground surveys replacing or optimizing $[2,3]$.

The purpose of the study was to evaluate the productivity of agrocoenosis on test plots in the Beya district of Khakasia based on Terra Modis satellite data.

\section{Methods}

The object of the study was the soil and vegetation cover of the arable land of the hilly steppe of the Beya region of Khakasia, used for crops (agrocoenosis), hayfields - preserved arable land (fallow) and not used fallow. Agricultural land was located in the complex landscapes of a hilly plain, where moisture is redistributed due to a surface effluent, which is associated with the development of erosion processes.

The work was based on MODIS data (https://lpdaacsvc.cr.usgs.gov/appeears): 1) MOD17A2H (gross primary productivity, $\mathrm{kg} / \mathrm{m}^{2}$ ) [4]; 2) MOD16A2 (evapotranspiration)

\footnotetext{
*Corresponding author: biosara@mail.ru
} 
[5]. Gross productivity for the season was determined by integrating the GPP curve for the period from May 1 to August 31.

Weather data provided by the site https://rp5.ru/. For regression, the calculation of the sum of positive temperatures was carried out for the period preceding the date of the survey: the sum of temperatures above $0{ }^{\circ} \mathrm{C}$ was calculated 8 times a day (the sum of temperatures above standard). This method showed higher correlation values on the data sample.

A general route study and the establishment of decoding features of soils in satellite images were carried out. According to the main sections (depth $1.5 \mathrm{~m}$ ), with precise reference to the terrain by GPS-navigator and digging $(0.8-0.5 \mathrm{~m})$, the genetic nomenclature of soils (types, subtypes, genera, species, varieties) was specified according to the classification [6]. Soil samples were taken from the genetic horizons of the soil profile for laboratory analysis and subsequent clarification of the diagnosis.

Test sites were located in the Beya vicinity (Beya district, Khakasia) on ordinary chernozems of different genera (calcareous, solonetzic, solonchakous), meadow-chernozem soils (solonchakous), as well as leached chernozems on the slopes of northern exposures adjacent to the forest-steppe (Fig. 1).

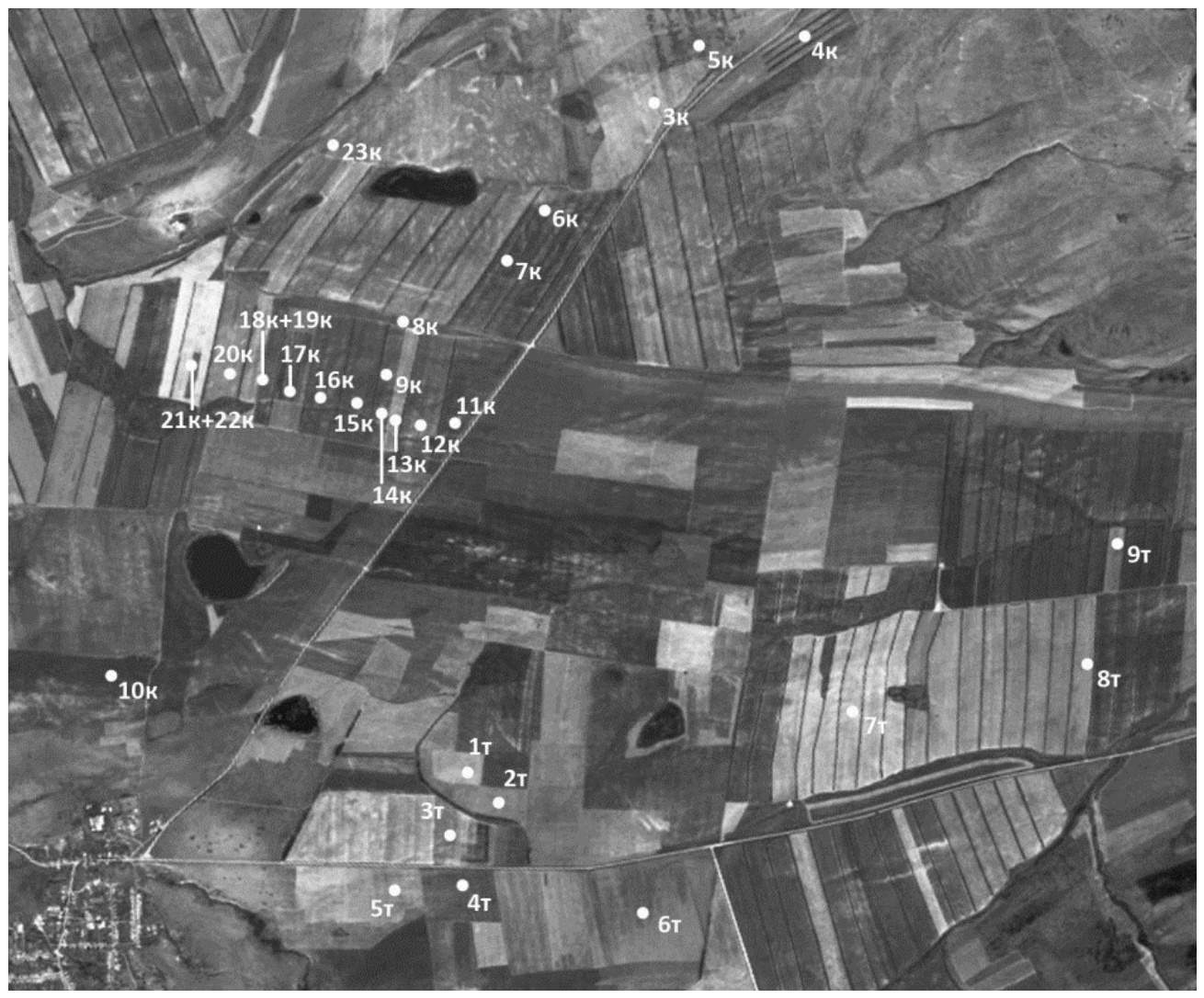

Fig. 1. Location and codes of agrocoenosis (NDVI, Sentinel, 2018): hayfields $-1 \kappa, 21$ $\kappa, 22 \kappa$; wheat $-11 \kappa, 12 \kappa, 14-15 \kappa, 16 \kappa, 18 \kappa, 19 \kappa, 20 \kappa$ and $10 \mathrm{~T}$; oats $-2 \kappa, 9 \mathrm{~T}$; fallow $-3 \kappa, 6 \kappa, 7 \kappa, 8 \kappa, 9 \kappa, 10 \kappa$; arable fields $-5 \kappa, 2 T, 4 T, 5 T, 4 \kappa, 23 \kappa, 1 T, 3 T$; barley $-13 \kappa, 17 \kappa$; buckwheat $-6 T$; Melilotus $-7 \mathrm{~T}$; Elytrigia repens + Onobrychis arenaria $-8 T$ 
The ones are the most fertile soils, both throughout the territory of Khakasia and on the site. Red-colored heavy loams and clays dominate among parent rocks in the study area. Leached chernozems are developed on eluvial-deluvial yellow-brown loams.

Geobotanical studies of fallows are observed in 2018 at test sites using the stationary area method [7, 8]. The productivity of agrocoenosis was determined by the standard method. Herbage was cut off at the surface of the soil on sites $1 \times 1 \mathrm{~m}^{2}$ in fivefold repetition. The phytomass of the fallows was divided into botanical and economic groups sedges, cereals, legumes, wormwood, different herbs, rags with mort-mass. The phytomass of agrocoenosis was divided into groups - the mass of ears, vegetative mass, the mass of weeds, dry grass and mortmass. Plants were weighed in a wet and air-dry state with an accuracy of $0.01 \mathrm{~g}$. Data were transferred in $\mathrm{kg} / \mathrm{m}^{2}[8,9]$.

Statistical analysis (regression, calculation of the confidence interval, arithmetic mean and standard deviation) was performed in Microsoft Excel.

\section{Results}

The total productivity of gross productivity for the growing season of 2018 was calculated according to Terra MODIS (Table 1).

As can be seen from table 1, the most minimal value of the indicator for wheat crops (20k) was $3.57 \mathrm{~kg} / \mathrm{m}^{2}$ on meadow chernozem solonchakous, with a sulphate-soda type of salinization. The limiting yield factor in this case, obviously, is salinization, especially soda - the most toxic for most plants.

On average, the integral wheat productivity for the growing season (2018) was $5.01 \pm$ $1.04 \mathrm{~kg} / \mathrm{m}^{2}$. For comparison, we present the phytomass of wheat sowing $(11 \mathrm{k})$ in the second decade of August. The phytomass of ears was $0.091 \mathrm{~kg} / \mathrm{m}^{2}$ in raw form $(0.061 \mathrm{~kg} /$ $\mathrm{m}^{2}$ in dry), the vegetative mass was $0.084(0.060) \mathrm{kg} / \mathrm{m}^{2}$, weeds $0.231(0.074) \mathrm{kg} / \mathrm{m}^{2}$, dry grass and mortmass $0.183(0.107) \mathrm{kg} / \mathrm{m}^{2}$.

During this period, the productivity of this agrocoenosis based on MODIS data was $0.0262 \mathrm{~kg} / \mathrm{m}^{2}$, aboveground phytomass was significantly higher $-0.589 \mathrm{~kg} / \mathrm{m}^{2}$ in raw form and 0.302 in dry form. The differences are explained by the phenological state of wheat and the presence of a significant amount of dry grass, which reduces the value of the indicator.

Similar indicators were observed for barley $\left(4.22\right.$ and $\left.4.82 \mathrm{~kg} / \mathrm{m}^{2}\right)$ and oats $(4.06$ and $5.65 \mathrm{~kg} / \mathrm{m}^{2}$ ). Ground-based studies have shown high grain yields in the contours: $4 T, 5 T$, $9 T$ and $10 T$. It is associated with increased moisture capacity of the heavy loamy ordinary and leached chernozems, as well as average indicators of their potential and effective fertility (humus content 4.5-5.6\%, mobile phosphorus and potassium, respectively 20.523.9 and $214-276 \mathrm{mg} / \mathrm{kg}$ of soil). A high yield was noted according to ground data in the contours of $9 T$ and $10 T$, which is associated with high fertility.

The barley was more productive than the wheat in accordance with ground-based data. So, the phytomass of barley ears $(13 \mathrm{k})$ is $0.149 \mathrm{~kg} / \mathrm{m}^{2}$ in raw form $\left(0.154 \mathrm{~kg} / \mathrm{m}^{2}\right.$ in dry), the vegetative mass is $0.117(0.126) \mathrm{kg} / \mathrm{m}^{2}$, weeds are $0.095(0.047) \mathrm{kg} / \mathrm{m}^{2}$, dry grass and mortmass $0.135(0.119) \mathrm{kg} / \mathrm{m}^{2}$.

Weed participation (Panicum miliaceum ssp. ruderale, Brassica napus, Elytrigia repens, Erodium stephanianum, Setaria viridis, Panicum dichotomiflorum, Nonea pulla, Oxybasis glauca, Thlaspi arvense) is small. For comparison, the yield of the main agricultural crops was, according to the results of the harvesting campaign in the Beya district as of September 30 (2018): for hay - 19.1, wheat -23.7 , barley -23.0 , oats -24.4 , buckwheat -9.1 centners per hectare.

Hayfields had values close to wheat; their projective cover did not exceed $50 \%$. The most productive were perennial grasses of the fourth year of use - Elytrigia repens + Onobrychis arenaria and Melilotus (7.41 and $\left.5.14 \mathrm{~kg} / \mathrm{m}^{2}\right)$. 
Table 1. Total seasonal productivity and evapotranspiration of agrocoenosis in test sites (Beya district)

\begin{tabular}{|c|c|c|c|c|c|c|c|c|c|}
\hline $\begin{array}{l}\text { The } \\
\text { code }\end{array}$ & $\mathrm{GPP}^{1}$ & $\mathrm{ET}^{2}$ & $\mathrm{R}^{23}$ & $\mathrm{R}^{24}$ & $\begin{array}{l}\text { The } \\
\text { code }\end{array}$ & $\underset{1}{\mathrm{GPP}}$ & $\mathrm{ET}^{2}$ & $\mathrm{R}^{23}$ & Код \\
\hline \multicolumn{5}{|c|}{ oats } & \multicolumn{5}{|c|}{ hayfields } \\
\hline $2 \kappa$ & 4.062 & 3611 & 0.654 & 0.272 & $1 \kappa$ & 4.82 & 2241 & 0.687 & 0.223 \\
\hline $9 T$ & 5.65 & 2505 & 0.632 & 0.188 & $21 \kappa$ & 4.43 & 1710 & 0.701 & 0.472 \\
\hline \multicolumn{5}{|c|}{ barley } & $22 \kappa$ & 5.32 & & 0.737 & 0.389 \\
\hline $13 \kappa$ & 4.22 & 1678 & 0.626 & 0.393 & \multicolumn{5}{|c|}{ fallow } \\
\hline $17 \kappa$ & 4.82 & 1973 & 0.736 & 0.324 & $3 \kappa$ & 4.56 & 1730 & 0.788 & 0.315 \\
\hline \multicolumn{5}{|c|}{ wheat } & $6 \kappa$ & 4.09 & 1875 & 0.627 & 0.274 \\
\hline $11 \kappa$ & 4.38 & 1661 & 0.619 & 0.441 & $7 \kappa$ & 4.26 & 2067 & 0.647 & 0.253 \\
\hline $12 \kappa$ & 4.22 & 1678 & 0.626 & 0.393 & $8 \kappa$ & 4.10 & 1861 & 0.651 & 0.319 \\
\hline $\begin{array}{c}14-15 \\
\kappa\end{array}$ & 4.66 & 1963 & 0.558 & 0.296 & $9 \kappa$ & 4.22 & 1678 & 0.626 & 0.393 \\
\hline $16 \kappa$ & 5.02 & 1987 & 0.666 & 0.426 & $10 \kappa$ & 5.12 & 2050 & 0.687 & 0.537 \\
\hline $18 \kappa$ & 4.90 & 1820 & 0.737 & 0.389 & \multicolumn{5}{|c|}{ Elytrigia repens + Onobrychis arenaria } \\
\hline $19 \kappa$ & 4.28 & 1950 & 0.582 & 0.344 & $8 T$ & 7.41 & 3011 & 0.747 & 0.233 \\
\hline $20 \kappa$ & 3.57 & 1950 & 0.644 & 0.365 & \multicolumn{5}{|c|}{ Melilotus } \\
\hline $10 T$ & 7.18 & 3007 & 0.655 & 0.324 & $7 \mathrm{~T}$ & 5.14 & 2072 & 0.704 & 0.455 \\
\hline \multicolumn{5}{|c|}{ arable fields } & \multicolumn{5}{|c|}{ buckwheat } \\
\hline $5 \kappa^{5}$ & 4.87 & 2100 & 0.792 & 0.354 & $6 \mathrm{~T}$ & 5.25 & 2326 & 0.583 & 0.203 \\
\hline $2 T^{5}$ & 5.16 & 2087 & 0.797 & 0.299 & \multicolumn{5}{|c|}{ arable fields } \\
\hline $4 T^{5}$ & 5.65 & 2248 & 0.740 & 0.387 & $4 \kappa$ & 4.56 & 2071 & 0.787 & 0.318 \\
\hline \multirow{3}{*}{$5 T^{5}$} & \multirow{3}{*}{6.77} & \multirow{3}{*}{2888} & \multirow{3}{*}{0.743} & \multirow{3}{*}{0.267} & $23 \kappa$ & 3.42 & 1665 & 0.514 & 0.264 \\
\hline & & & & & $1 T$ & 5.21 & 1892 & 0.731 & 0.253 \\
\hline & & & & & $3 T$ & 4.26 & 1643 & 0.508 & 0.279 \\
\hline \multicolumn{10}{|c|}{$\begin{array}{l}1-\text { gross primary productivity, } \mathrm{kg} \\
2-\text { evapotranspiration, } \mathrm{kg} / \mathrm{m}^{2}\end{array}$} \\
\hline
\end{tabular}

The productivity of the fallows varied slightly from 4.09 to $5.12 \mathrm{~kg} / \mathrm{m}^{2}$. For comparison, we present the ground data for the $8 \mathrm{k}$ plot (Elytrigia repens-Vicia hirsuta) amounted to $0.452 \mathrm{~kg} / \mathrm{m}^{2}$ in raw form and $0.288 \mathrm{~kg} / \mathrm{m}^{2}$ in dry: of which cereals -0.121 $(0.063) \mathrm{kg} / \mathrm{m}^{2}$, wormwood $-0.077(0.031) \mathrm{kg} / \mathrm{m}^{2}$, legumes $-0.018(0.008) \mathrm{kg} / \mathrm{m}^{2}$, different herbs $-0.042(0.023) \mathrm{kg} / \mathrm{m}^{2}$, dry grass and mortmass $-0.193(0.163) \mathrm{kg} / \mathrm{m}^{2}$.

During the season, the phytomass of agrocoenosis intensively increased at the end of May, and then the development maximum remained until the beginning of June (Fig. 2). Further, the mass decreased except for two peaks in early July and August, associated with favorable weather conditions. The main seasonal increase in GPP was in early June, the end of the first decade of July, the end of the third decades of July.

Evapotranspiration (ET) can serve as an indirect method for assessing soil moisture content, and the GPP is higher the higher the ET (Table 1). This indicator increases with significant phytomass (due to the volume of the transpiration surface of the leaves), good water availability, and partly with a decrease in projective cover. It is worth noting that the vegetation cover to some extent prevents the drying out of the soil. 


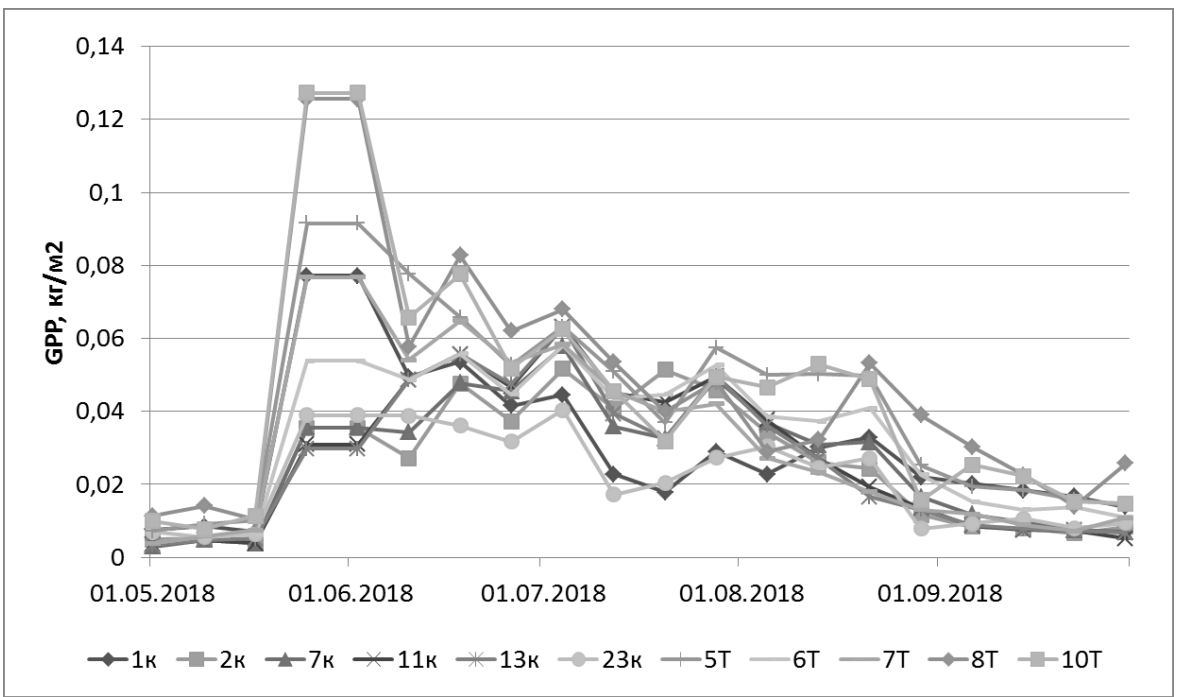

Fig. 2. Seasonal productivity of individual agrocoenosis in test plots

The relationship between weather data and distance indicators allows you to determine the degree of weather sensitivity of crops. On average, for the examined agrocoenoses, the GPP indicators are associated positively with the sum of positive temperatures $\left(R^{2}=0.673\right)$, to a lesser extent $\left(\mathrm{R}^{2}=0.333\right)$ with a hydrothermal coefficient.

Long-term changes of the productivity were also analized for individual agrocoenosis (Table 2).

Table 2. Average long-term indicators of gross primary production of agrocoenosis of Khakasia (Beya district) from 2000 to 2018

\begin{tabular}{|c|c|c|c|c|c|c|}
\hline \multirow{2}{*}{$\begin{array}{l}\text { agrocoeno } \\
\text { sis }\end{array}$} & \multirow{2}{*}{$\bar{X}$ and $\sigma$} & \multicolumn{2}{|c|}{ Confidence interval } & \multirow{2}{*}{$\begin{array}{c}\text { GPP } \\
(2018), \\
\mathrm{kg} / \mathrm{m}^{2}\end{array}$} & \multirow[b]{2}{*}{ Min } & \multirow[b]{2}{*}{ Max } \\
\hline & & lower & upper & & & \\
\hline $1 T$ & $4.65 \pm 0.45$ & 4.43 & 4.86 & 5.21 & 3.91 & 5.50 \\
\hline $2 T$ & $4.58 \pm 0.47$ & 4.35 & 4.81 & 5.16 & 3.87 & 5.55 \\
\hline $3 T$ & $4.28 \pm 0.45$ & 4.06 & 4.49 & 4.26 & 3.43 & 5.24 \\
\hline $4 T$ & $4.83 \pm 0.71$ & 4.49 & 5.18 & 5.65 & 3.27 & 5.92 \\
\hline $5 T$ & $5.93 \pm 0.57$ & 5.66 & 6.21 & 6.77 & 5.05 & 7.02 \\
\hline $\begin{array}{l}\text { Buck } \\
\text { wheat }\end{array}$ & $4.50 \pm 0.70$ & 4.17 & 4.84 & 5.25 & 3.04 & 5.87 \\
\hline Melilotus & $4.22 \pm 0.45$ & 4.00 & 4.44 & 5.14 & 3.29 & 5.14 \\
\hline $\begin{array}{c}\text { Elytrigia } \\
+ \text { Onobry- } \\
\text { chis }\end{array}$ & $5.24 \pm 1.14$ & 4.69 & 5.79 & 7.41 & 3.63 & 7.41 \\
\hline Oats $(9 T)$ & $5.02 \pm 0.47$ & 4.79 & 5.24 & 5.65 & 4.20 & 5.96 \\
\hline $\begin{array}{l}\text { Wheat } \\
(10 T)\end{array}$ & $6.04 \pm 0.55$ & 5.77 & 6.30 & 7.18 & 5.07 & 7.18 \\
\hline
\end{tabular}

The most productive areas were those where in 2018 were located arable fields $(5 T)$, wheat (10 T), Elytrigia + Onobrychis, and oats $(9 \mathrm{~T})$. The remaining communities had 
lower rates. The largest positive increase in GPP among the examined sites was observed in 2003-2004, and in 2015-2016. In 2018, an increase in productivity was also noted, and even higher in comparison with 2003-2004. The productivity of the site with perennial herbs (Elytrigia + Onobrychis, Melilotus) is growing rapidly.

\section{Conclusion}

Thus, the gross productivity of agrocoenosis for the season in the study area was calculated and the differences between them were determined. Least of all phytomass were individual arable fields and low-yielding wheat crops $\left(3.6 \mathrm{~kg} / \mathrm{m}^{2}\right)$, fallows, and most of all perennial grasses and high-yielding wheat and oats (up to $5.02-7.41 \mathrm{~kg} / \mathrm{m}^{2}$ ).

Terra Modis data allows you to rank phytocoenosis by productivity and choose the optimal crops for growing in a particular area. Terra Modis satellite data showed a positive correlation with ground-based data and can be used for agroecological monitoring and optimization of land reclamation in the Beya region. The results obtained are of practical interest for the optimal placement of crops and agricultural cultivation technologies; monitoring fertility and the state of agrocoenosis; calculation of their normative productivity.

The study was supported by state contract No. F.2018.387388 (08.13.2018).

\section{References}

1. E. G. Yazikov, V. M. Khudyakov, S. V. Azarova, Bulletin of the Tomsk Polytechnic University. Geo-Resource Engineering, 307(4), 55-59 (2004)

2. E. Yu. Zhukova, A. P. Shevyrnogov, V. M. Zhukova, T. M. Zorkina, I. Yu. Pugacheva, Bulletin of Tomsk State University, 323, 354-357 (2009)

3. F. V. Eroshenko, N. G. Lapenko, I. G. Storchak, Bulletin of the Orenburg State Agrarian University, 5(73) 14-17 (2018)

4. S. Running, Q. Mu, M. Zhao, doi: 10.5067 / MODIS / MOD17A2H.006 (2015)

5. S. Running, Q. Mu, M. Zhao, doi: 10.5067 / MODIS / MOD16A2.006 (2017).

6. V. V. Egorov, E. N. Ivanova, V. M. Fridland, Classification and soil diagnostics of the USSR (Moscow B, 1977)

7. E. M. Lavrenko, A. A. Korchagin, Field geobotany (Leningrad, 1976)

8. T. M. Zorkina, Phytocenology (Abakan, 2003)

9. I. V. Larin, Meadow farming and pasture farming (Moscow-Leningrad, 1956) 